\title{
MONITORING TWITTER STRATEGIES TO DISCOVER RESONATING TOPICS: THE CASE OF THE UNDP
}

\section{Seguimiento de estrategias de Twitter para descubrir temas de gran difusión: el caso del PNUD}

Mike Thelwall and Brian Cugelman

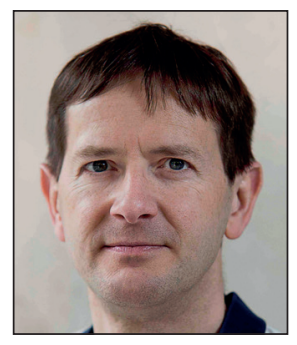

Mike Thelwall is head of the Statistical Cybermetrics Research Group, School of Mathematics and Computing, University of Wolverhampton, UK. His degrees are all in Maths, but he develops social science software and methods to research the social web data, including sentiment analysis, altmetrics and content analysis for Twitter, YouTube, blogs and the general Web. Most of the software is free online for academic use and is written from a social sciences perspective -to help understand social processes. He has written 301 refereed journal articles, 23 chapters and two books, including Introduction to Webometrics. He is an associate editor of the Journal of the Association for Information Science and Technology and sits on three other editorial boards. http://orcid.org/0000-0001-6065-205X

Statistical Cybermetrics Research Group, School of Mathematics and Computer Science, University of Wolverhampton Wulfruna Street, Wolverhampton WV1 1LY, UK m.thelwall@wlv.ac.uk

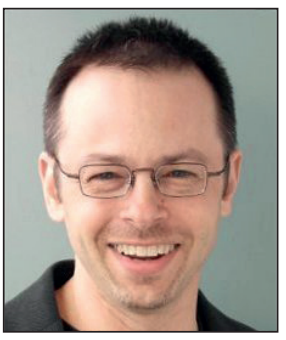

Brian Cugelman is a senior scientist, director of AlterSpark, Toronto, Canada. Since 1997 he has built an extensive career in social mobilization, digital engagement, and program evaluation. Brian obtained his PhD in Online Social Marketing with the Statistical Cybermetrics Research Group, a world-leading Internet research team. He obtained his Masters in Business and Computers. He is published in JMIR, the world's top e-health journal. The United Nations General Assembly has recognized the impact of his digital campaigning work. He has been invited to act as an expert advisor for the World Anti-Doping Agency, the Heart and Stroke Foundation, and the annual International Conference on Persuasive Technology. The Pentagon also invited Brian to present his research on persuasive design to the Cyber Influence Project.

http://orcid.org/0000-0002-3680-4700

AlterSpark Corp., 193 Augusta Avenue, Lower level, Toronto, Ontario M5T 2L4, Canada brian@alterspark.com

\begin{abstract}
Many organizations use social media to attract supporters, disseminate information and advocate change. Services like Twitter can theoretically deliver messages to a huge audience that would be difficult to reach by other means. This article introduces a method to monitor an organization's Twitter strategy and applies it to tweets from United Nations Development Programme (UNDP) accounts. The Resonating Topic Method uses automatic analyses with free software to detect successful themes within the organization's tweets, categorizes the most successful tweets, and analyses a comparable organization to identify new successful strategies. In the case of UNDP tweets from November 2014 to March 2015, the results confirm the importance of official social media accounts as well as those of high profile individuals and general supporters. Official accounts seem to be more successful at encouraging action, which is a critical aspect of social media campaigning. An analysis of Oxfam found a successful social media approach that the UNDP had not adopted, showing the value of analyzing other organizations to find potential strategy gaps.
\end{abstract}

\section{Keywords}

Twitter; Social media; Social networks; Communication strategies; Free software; Mozdeh.

\section{Resumen}

Muchas organizaciones usan las redes sociales para atraer simpatizantes, difundir información y promover el cambio. Servicios como Twitter pueden distribuir mensajes a una gran audiencia a la que sería difícil llegar por otros medios. Este artículo presenta un método para supervisar la estrategia de Twitter de una organización y la aplica a los tweets de las cuentas del Programa de las Naciones Unidas para el Desarrollo (PNUD). El método Resonating Topic utiliza análisis automáticos realizados con software libre para detectar los temas que han tenido más resonancia en los tweets de la organización, categoriza 
los tweets más exitosos y analiza los tweets de otras organizaciones comparables para identificar nuevas estrategias que sean también exitosas. En el caso de los tweets del PNUD entre noviembre de 2014 y marzo de 2015, los resultados confirman la importancia de las cuentas oficiales de los medios de comunicación social, así como de las personas de alto perfil y de los simpatizantes. Las cuentas oficiales parecen tener más éxito para promover acciones, que es un aspecto crítico en las campañas de los medios sociales. Un análisis de Oxfam encontró un enfoque exitoso en los medios sociales que el PNUD no había adoptado, mostrando el valor de analizar otras organizaciones para mejorar y para encontrar posibles fallos de estrategia.

\section{Palabras clave}

Twitter; Medios de comunicación social; Redes sociales; Estrategias de comunicación; Software gratuito; Mozdeh.

Thelwall, Mike; Cugelman, Brian (2017). "Monitoring Twitter strategies to discover resonating topics: The case of the UNDP”. El profesional de la información, v. 26, n. 4, pp. 649-661.

https://doi.org/10.3145/epi.2017.jul.09

\section{Introduction}

Many organizations communicate with sections of the population and media to persuade citizens to take specific actions, or to generate public support that can be leveraged to influence government policies. These practices are common among advocacy groups, such as environmental pressure groups or anti-poverty campaigns, and may be amongst the core goals of other types of organizations, such as disability-related charities or disaster relief committees. Many seek to impact their audiences' behaviours through websites and online interventions (Cugelman; Thelwall; Dawes, 2011; Kim et al., 2014) and social media (Bortree; Seltzer, 2009; Edwards; Hoefer, 2010; Lovejoy; Waters; Saxton, 2012). In the USA, for example, major advocacy groups use social media daily and believe that it helps them achieve their goals (Obar; Zube; Lampe, 2012). Social media campaigns can be relatively cheap (Karaduman, 2013), fast, with a wide potential geographic reach, and supporters can help to share messages with their online networks. Nevertheless, social media use is time-consuming (Briones et al., 2011), campaigns are ineffective for people that are not online and the competition for attention in the social web (e.g., $30 \%$ of the tweets seen come from $0.05 \%$ of the tweeters: $\mathbf{W u}$ et al., 2011) makes resources necessary to compete effectively (Thrall; Stecula; Sweet, 2014).

It is useful to assess the influence of an organisation's online campaign as the first step towards assessing its overall effectiveness or to detect which aspects contributed most or least

It is difficult to assess the impact of an online intervention unless the goal is related to a traceable online transaction, such as an electronic donation. Nevertheless, it is useful to assess the influence of an organisation's online campaign as the first step towards assessing its overall effectiveness or to detect which aspects contributed most or least. Several studies have attempted to do this, as reviewed below, but there is little systematic research and no academic recommendations for methods to use for monitoring. This is part of a wider lack of practical research into professional skills for advocacy organizations (Almog-Bar; Schmid, 2014). This article addresses this gap for Twitter, describing a set of simple techniques, the Resonating Topic Method, that can be carried out with free software to help identify best practice strategies for an organisation's online campaign.

This article describes a set of simple techniques, the Resonating Topic Method, that can be carried out with free software to help identify best practice strategies for an organisation's online campaign

The new method is demonstrated here by applying it to the United Nations Development Programme (UNDP). The UNDP was founded by the United Nations in 1965 by merging its financial and technical aid functions to promote development in poor countries (Rist, 2014). Its annual budget had risen to approximately 5 billion USD in 2013, which was mainly spent in Asia and the Pacific, Africa, and Latin America and the Caribbean (UNDP, 2014). The UNDP aims to support economic and human development efforts, guided in part by the following eight Millennium Development Goals that were set in 2000 for achievement in 2015 (UN, 2015):

- Eradicate extreme poverty and hunger;

- Achieve universal primary education;

- Promote gender equality and empower women;

- Reduce child mortality;

- Improve maternal health;

- Combat HIV/AIDS, malaria, and other diseases;

- Ensure environmental sustainability;

- Global partnership for development.

\section{Theoretical background: Advocacy and related strategies}

Advocacy activities designed to influence government policy use strategies from lobbyists to grassroots campaigns to achieve social, environmental, health and public safety improvements in their community. Non-profit human service organizations, such as those providing shelter or food for 
the homeless, are also increasingly using advocacy to help achieve their wider goals (Almog-Bar; Schmid, 2014; Berry, 1977). Although many groups rely upon private insider strategies for this, such as lobbying (Gormley; Cymrot, 2006; McKay, 2011; Mosley, 2011), the focus here is on the use of strategies to engage the wider public. A typology of advocacy strategies found four out of eleven aimed at the public:

- grassroots lobbying;

- public events and direct action;

- public education; and

- voter registration and education (Guo; Saxton, 2010).

Not all NGOs seek to communicate widely, however (GálvezRodríguez; Caba-Pérez; López-Godoy, 2014).

Many Non-Governmental Organizations (NGOs) employ mass communication campaigns to influence the media and public opinion to set policy agendas (Soroka, 2002). Mass communication campaigns may also target wider behavioral change through raising awareness (e.g., about violence against women), increasing knowledge (e.g., about health issues: Neiger et al., 2013; Ramanadhan et al., 2013). Campaigns may also solicit public donations (Saxton; Neely; Guo, 2014; Phethean; Tiropanis; Harris, 2013) or explain government policy (Khan et al., 2014).

It is difficult to measure the overall effects of individual advocacy strategies because of the lack of clarity about what constitutes success and the use of multiple simultaneous strategies from different organizations with overlapping objectives. There are, however, many theories about the most effective advocacy strategies. Punctuated equilibrium theory argues that policy changes tend to be sudden rather than gradual, but that the point in time when the change occurs may not be predictable (Baumgartner; Jones; Mortensen, 2014). Thus, organizations may continually press for change across a broad front but focus resources and make policy alliances (Covey, 1995) at pivotal moments. Successful outcomes vary from an issue becoming taken seriously for the first time to the organization's perspective being accepted as the norm (Casey, 2011). NGOs harness many strategies to achieve their goals and coordinate them for specific campaigns. For example, Oxfam's climate change campaign 2008-2009 blended, "research, alliances, popular mobilization, media work, and lobbying" (Cugelman; Otero, 2010, p. 6). Advocacy strategies may also focus on longer term goals. Reflecting this, an investigation into Australian climate change NGOs found that none focused exclusively on promoting either incremental change or revolutionary change (Hall; Taplin, 2007).

Previous investigations have found factors that influence the success of some types of mass campaigns. For example, public acknowledgements help with fundraising from some types of individuals (Mason, 2016; Shaker; Borden; Kienker, 2016). Campaigns to generate volunteers also have an obvious indicator of success (the number of recruits) and there is a body of knowledge about who and how to recruit (Dury et al., 2015). Web-based initiatives can employ indirect evidence, such as website visitors or retweeting, or may use online questionnaires for visitors. Using the online questionnaire approach, for example, professional website design has been shown to help initiatives to promote behavioral change (Cugelman; Thelwall; Dawes, 2011). Social media strategies have become increasingly adopted, and these are discussed separately below.

Advocacy groups could reasonably expect successful messages to be retweeted by their supporters to reach a wider audience, increasing the chance of achieving wider impact

\subsection{Reaching an audience on Twitter}

An influential mass communication theory argues that an important way in which the public is influenced is that mass media information is transmitted to local opinion leaders, who then influence their circle (Katz, 1957). This seems to occur in Twitter, with typical users viewing tweets as retweets from friends rather than directly (Wu et al., 2011). From this, advocacy groups could reasonably expect successful messages to be retweeted by their supporters to reach a wider audience, increasing the chance of achieving wider impact.

Retweeting is a reasonable indicator of success for a tweet because it suggests both approval and dissemination (Saxton; Waters, 2014), although there will be exceptions. Retweet counts are simple to obtain from Twitter and because of this, much is known about the factors that influence successful tweets. A tweet is more likely to be retweeted if its author has many followers, follows many others and is a long-term Twitter user, or if the tweet contains a hashtag or URL (Suh et al., 2010). Spam-like hashtags decrease retweeting, however, such as \#followyouback and \#instantfollow, whereas youth-oriented hashtags are amongst the most successful (Petrovic; Osborne; Lavrenko, 2011). More active authors are not more likely to be retweeted, however (Suh et al., 2010) and are not seen as more credible (Westerman; Spence; Van-Der-Heide, 2014). A successful strategy to gain influence on Twitter is to tweet consistently on a single topic (Cha et al., 2010), which would presumably be natural for advocacy groups.

Some studies have evaluated offline successes for social media messages. A survey of Italians tweeting about elections found a connection between getting more information from Twitter and participating more in the elections, although no cause and effect relationship was established (Vaccari et al., 2015). Similarly, social media strategies can be successful at eliciting small donations, especially for health organizations (Saxton; Wang, 2014).

Twitter is also important in politics, particularly during elections. Investigations of this have not tended to focus on evaluating audience engagement, but on the level of uptake amongst politicians (Vergeer; Hermans, 2013) on counting tweets to predict results, or their use by the media (Anstead; O'Loughlin, 2015). The fast reaction times of social media are also helpful when organising offline protest movements (Gerbaudo, 2012; Ghonim, 2012; Howard; Hussain, 2013). 


\subsection{Advocacy strategies on Twitter}

Tweets from large US advocacy groups can be classified into three categories:

- disseminating information (e.g., news);

- directly engaging with followers or members of the community; and

- promoting a specific action (Lovejoy; Saxton, 2012).

Building on this an analysis of the social media strategies of 188 tax-exempt non-profit advocacy organizations in the USA (Guo; Saxton, 2014) found that they tended to pursue a three-stage strategy:

- contacting potential supporters;

- maintaining relationships with the people contacted; and

- encouraging supporters to act.

These three activities may happen in parallel to some extent but calls for action presumably occur at key points in time. The balance between the three stages varies by organisation, however (e.g., sport for development: Svensson; Mahoney; Hambrick, 2015). NGOs also sometimes need to explain their position or resource usage in the media (Carroll et al., 2014). For controversial issues, Twitter might be used to argue for a perspective (Auger, 2013) or to help build coalitions (Sundstrom; Briones; Janoske, 2013). Thus, deviations from the above three stage strategy can be expected.

\section{Retweeting is a reasonable indicator of success for a tweet because it suggests both approval and dissemination}

Within Facebook, informational messages (stages 1 or 2) are more likely to be shared whereas messages promoting action (stage 3 ) or engaging with others (stage 2 ) are most likely to be liked or commented on and so all types can be successful (Saxton; Waters, 2014; Guidry; Waters; Saxton, 2014).

There is some evidence that online engagement can be effective at generating and retaining interest (stages 1 and 2). Within Facebook, for example, organizations that use their profiles to directly engage visitors (stage 1) can generate reactions and repeat visits (Bortree; Seltzer, 2009) and can reach a younger audience (Briones et al., 2011). This strategy of direct engagement does not seem to be extensively used by non-profit organisations (Lovejoy; Waters; Saxton, 2012), perhaps because it is time-consuming to contact people individually.

\section{The Resonating Topic Method}

This method addresses the need for an overall systematic strategy to monitor an organisation's Twitter campaign in the sense of discovering its most successful attributes. The goal is not to evaluate overall campaign success (e.g., policy changes, donations, recruitment) but to identify factors that will help future campaigns to be more successful. It is supported by the free software Mozdeh and more details are given in the methods section.

http://mozdeh.wlv.ac.uk
Collecting tweets. The first stage is to collect all tweets generated by the organisation or campaign. These may be tweets from the known supporters of the campaign. If the campaign is the activity of a single organisation (e.g., the UNDP) then this set may be the official organisation accounts. If there is a campaign hashtag, then tweets with these may also be collected. Whilst tweets from accounts are (currently) free to collect, Twitter charges to automatically download tweets older than a week unless they come from named accounts and so including tweets containing a hashtag has financial implications. Thus, it may be a practical necessity to focus on a set of key Twitter accounts.

\section{A successful strategy to gain influence on Twitter is to tweet consistently on a single topic}

Word frequency analysis to detect retweeted topics. As discussed above, retweeting is the best intrinsic indicator of success for Twitter since retweet data is readily available and reflects both endorsement (usually) and the tweet reaching a wider potential audience than campaign followers. A simple automatic method to detect topics that are relatively successful within an organization's tweets is therefore to find words that occur more often in tweets that were retweeted in comparison to those that were not. This identification can be carried out quickly and automatically with Mozdeh, even on large numbers of tweets. Any automatic strategy is likely to give less nuanced information than manual approaches, such as content analysis, but has the practical advantage of being quick and hence inexpensive and repeatable for ongoing monitoring. In addition, automatic approaches may detect trends that human experts may overlook due to their unexpectedness or due to the pre-conceptions of the human experts. This method requires an artificial split between more and less successful tweets based on a cut-off retweet count that depends on the success of the organisation. For example, this might be the median number of retweets for the organisation's tweets or a higher figure if the goal was to focus on a smaller proportion of more highly successful tweets. The list of more retweeted words must then be manually examined to check for patterns or topics to give insights into why some of the organisation's tweets resonated more than others. The topics should be cross-referenced against the organisation's core goals to evaluate their importance and contributions.

If the organisation's tweeters naturally split into subgroups (e.g., officials/employees/supporters/nationality) then it may be helpful to analyse each major group separately. Any splitting of the data reduces the statistical power of the word frequency approach and so the data should only be split if the subgroups are substantially different from each other.

Properties of individual highly retweeted tweets. An organization's most retweeted messages are particularly important because they are likely to have reached the largest audience and to have evoked the greatest user behaviour and social diffusion. It is likely that most of an organization's tweets will not be retweeted and only a small percentage 
will be extensively retweeted. These should therefore be analysed individually rather than with the word frequency approach above that is used to detect underlying trends. Understanding the reasons for the success of these tweets can help an organization to plan successful future social media strategies. The following properties are likely to be important for the success of a tweet.

- The tweeter authority -if the tweeter is well known or a figurehead for the organization.

- The number of followers of the tweeter.

- The topic of the tweet.

- The timeliness of the tweet, such as a date or a breaking news story.

- The novel aspect of the tweet that resonated in Twitter, if any.

As for the word frequency approach, the results should be cross-referenced against the organisation's core goals to evaluate their importance and contributions.

\section{Automatic approaches may detect trends that human experts may overlook due to their unexpectedness or due to the pre-conceptions of the human experts}

Analysis of a comparable organization. The methods described above give insights into successful topics and tactics but do not reveal anything about strategies that were not tried. For this, the methods can be repeated for comparator organizations to reveal successful strategies that could be adopted in the future. The comparator analysis may also reveal successes for the comparator organization for strategies that the evaluated organization had been less successful with. This could be useful encouragement to persist with apparently unsuccessful strategies in the hope that they will be successful later and may suggest better ways to pursue the same strategy.

\section{Research questions}

Despite prior investigations into how and why advocacy-related organizations use social media, there do not seem to have been any proposals for methods for advocacy groups to evaluate which content strategies resonate with the public. One partial exception is a list of potential Twitter metrics, ranging from a simple count of an organization's tweets and followers (Neiger et al., 2013).

The overarching goal of this paper is to introduce the Resonating Topic Method for ongoing assessments of Twitter content strategies by organizations working to engage public audiences. This paper demonstrates the method through an extended example and assesses it for plausibility, driven by the following research questions:
- Can the Resonating Topic Method produce plausible insights into successful topics and tactics within an organization's Twitter campaign?

- Can the Resonating Topic Method produce plausible insights into alternative Twitter topics and tactics that the organization has not used but that might be successful with the same target audience?

The research questions emphasize a weak level of evidence -plausibility rather than concrete verification. This is appropriate for an initial study and future investigations are needed to give evidence about the effectiveness of the method in other contexts and with different evaluation criteria.

\section{The Resonating Topic Method for the UNDP}

This section describes the Resonating Topic Method applied to the UNDP using the free software Mozdeh: http://mozdeh.wlv.ac.uk

\subsection{Collecting campaign tweets}

The first stage was to identify UNDP Twitter accounts. An official UN website list of accounts was used for this:

http://www.un.org/social

In addition to the official accounts, those of individual employees that tweet to spread the organization's message were also included from an official Twitter list:

https://twitter.com/UNDP/lists/UNDP-staff-members/ members

UNDP communication staff verified that these two lists represented the institution's most comprehensive lists of official Twitter accounts, and relevant staff accounts. Since both official accounts and active personal accounts promote the UNDP goals, it makes sense to analyse them separately to identify the relative strengths of both. This step is in addition to the basic Resonating Topic Method.

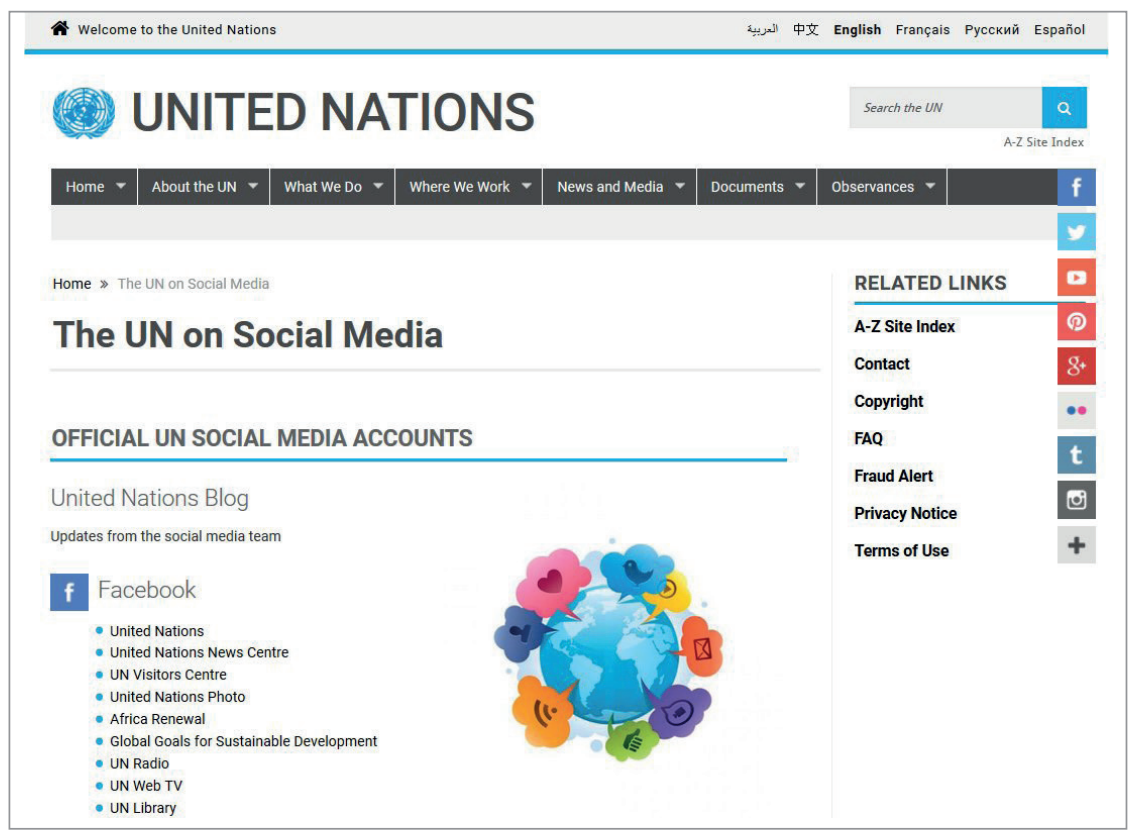

http://www.un.org/social 
The next stage was to collect the tweets and retweet counts from each Twitter account using Mozdeh's timelines data collection section. The list of tweets returned by Twitter was the most recent approximately 3,200 for each account, a Twitter technical limitation, and so was incomplete for very active users. The set returned for each user includes retweets by the account as well as their own original tweets. Retweets of others' tweets were excluded from the analysis because they do not primarily reflect activities initiated by the UNDP. There were 13,061 tweets from corporate accounts and 168,925 from personal accounts.

\subsection{Word frequency analysis to detect retweeted topics}

Automatic word frequency analysis was used to detect terms that occurred more in UNDP tweets that were retweeted compared to those that were not. This was achieved in Mozdeh by setting the number of retweets to 1 and then clicking the Calculate Word Frequencies button. This compares the words that occur in retweeted tweets to those that are in tweets that are not retweeted. For each word in both sets of tweets, it calculates the proportion of tweets containing it. For example, suppose that \#womensvoice occurs in 10 out of 100 tweets that were retweeted (10\%) but 20 out of 1000 tweets that were not retweeted $(2 \%)$. This suggests that tweets with \#womensvoice in are more likely to be retweeted. The results are reported in a ranked list of the terms most likely to be retweeted. The term ranking uses the difference in proportions test. This assesses the statistical significance of the difference between two proportions ( $10 \%$ and $2 \%$ in the above example). This test calculates a Z-value from the two proportions that is approximately normally distributed, with larger values indicating that the difference between the two proportions is less likely to have occurred by chance. This test is statistically better than comparing the differences in percentages.

The top terms in the ranked list were manually examined to identify important topics and underlying themes. A weakness is that the same topic or theme may be represented by multiple words. For example, both terms domestic and violence may be in the list if domestic violence tweets are frequently retweeted. In addition, polysemous terms and terms that are used in a variety of contexts may not occur in the list if some of their uses do not associate with higher retweeting. To illustrate this, if tweets highlighting violence against women tend to be retweeted but tweets about women in politics don't, then the term women might not be in the top ranked set, although the terms violence and against might.

It may not be clear why some of the terms are in the list if they do not unambiguously associate with a specific topic.
To identify the theme associated with such terms, tweets containing them were systematically read. In addition, Mozdeh was used to identify other words that tend to occur in the same tweet by repeating the word frequency procedure above but using the word as the search term in Mozdeh rather than setting the retweet threshold to 1 . This generated a list of words that often occur in the same tweets as the search terms to give insights into the contexts in which they were tweeted.

\section{Oxfam was chosen because of its large size, international presence, indepen- dence from the UN and similar goals}

\subsection{Properties of individual highly retweeted tweets}

The top ten UNDP tweets were individually examined for topic, timeliness and novel aspect as well as for tweeter authority and followers, to identify why they had been successful. These properties were cross-referenced with tweets that did not get retweeted to ensure that properties that were common to many tweets in the set were ignored. In addition, the top tweets were classified for the type of impact that they aim at, relative to the UNDP's goals, and for their primary topic. In both cases an informal content analysis was used that was inductive but guided by existing knowledge of the UNDP's activities and strategies. The results should help the UNDP to evaluate more precisely the impact of its Twitter engagement.

\subsection{Analysis of a comparable organization}

Many organizations share goals with the UNDP, including government international development agencies, such as the UK Department for International Development (DFID) or the United States Agency for International Development (USAID). There are also related UN agencies, including the World Bank, UN Women, Unicef, and Unaids as well as non-profit orga- 
Table 1. The top 10 terms for retweeting from the 13,061 UNDP corporate tweets identified, 6,180 of which were retweeted.

\begin{tabular}{|c|c|c|c|c|c|c|}
\hline \multirow{2}{*}{ Term } & \multicolumn{2}{|c|}{ Matches } & \multicolumn{2}{|c|}{ Non-matches } & \multirow{2}{*}{$\mathbf{Z}^{*}$} & \multirow{2}{*}{ Comment } \\
\hline & $\mathbf{n}$ & $\%$ & $\mathbf{n}$ & $\%$ & & \\
\hline our & 763 & 12.3 & 361 & 5.2 & 14.4 & UNDP openness drive; updates \\
\hline how & 699 & 11.3 & 314 & 4.6 & 14.4 & Explanations of possible solutions or actions \\
\hline in & 2,396 & 38.8 & 1,957 & 28.4 & 12.5 & [not clear] \\
\hline blog & 285 & 4.6 & 111 & 1.6 & 10.0 & Tweets linking to blog posts \\
\hline to & 1,897 & 30.7 & 1,639 & 23.8 & 8.8 & [not clear] \\
\hline \#2014 & 82 & 1.3 & 7 & 0.1 & 8.5 & Tweets reviewing the UNDP's activities in 2014 \\
\hline \#EbolaResponse & 228 & 3.7 & 96 & 1.4 & 8.4 & Responses to Ebola \\
\hline we & 509 & 8.2 & 331 & 4.8 & 8.0 & UNDP openness drive; updates \\
\hline \#OpenUNDP & 53 & 0.9 & 1 & 0.0 & 7.5 & UNDP openness drive \\
\hline we're & 154 & 2.5 & 58 & 0.8 & 7.4 & UNDP openness drive; updates \\
\hline
\end{tabular}

$* Z$ values are for a difference between proportions test for matches and non-matches.

nizations such as the International Institute for Sustainable Development, Oxfam, the International Rescue Committee (IRC), and Save the Children. Oxfam was chosen because of its large size, international presence, independence from the $U N$ and similar goals. Nevertheless, Oxfam has substantial differences from the UNDP, such as the need for fund raising, involvement in grassroots lobbying, substantial work unrelated to international development, and its ability to take sides in political debates. Oxfam also probably attracts many followers from the public, whereas the UNDP primarily services institutional constituents, including governments, NGOs, and scholars. Because of these differences in target groups and activities, any conclusions from the comparisons should be interpreted cautiously.

\section{Results}

To avoid overloading this paper with information, the tables focus on the top 10 items in each analysis but in practical applications it would be better to start with a much larger list and analyse a larger number of items, stopping when no new insights were gained.

\subsection{UNDP tweet word frequency analysis to detect retweeted topics}

The top terms analysis for corporate tweets (Table 1 ) reveals that corporate tweets describing what the UNDP was doing (using terms like we, our) were the most successful. This is also reflected in the \#OpenUNDP hashtag, which is associated with a drive for openness from the UNDP (see also Fox, 2010). The top terms co-occurring with our were: chief, \#OpenUNDP, latest, and project, confirming this characterization. Tweets linking to a blog post were also more retweeted. In terms of topics, the UNDP Ebola response was particularly popular for retweeting.

For the personal tweets, details of the United Nations mission in the Republic of South Sudan dominated the results, although Myanmar was also included (Table 2). These tweets may have been retweeted for their newsworthiness and as a direct source of information about an important intervention. South Sudan is a UN issue rather than a UNDP issue, which may be a reason why it is not in the top corporate UNDP tweets.

Table 2. The top 10 terms for retweeting from the 168,925 UNDP personal tweets identified, 32,075 of which were retweeted.

\begin{tabular}{|c|c|c|c|c|c|c|}
\hline \multirow{2}{*}{ Term } & \multicolumn{2}{|c|}{ Matches } & \multicolumn{2}{|c|}{ Non-matches } & \multirow{2}{*}{$\mathbf{Z}^{*}$} & \multirow{2}{*}{ Comment } \\
\hline & $\mathbf{n}$ & $\%$ & $\mathbf{n}$ & $\%$ & & \\
\hline \#southsudan & 840 & 2.6 & 497 & 0.4 & 41.0 & South Sudan \\
\hline \#unmiss & 240 & 0.7 & 47 & 0.0 & 27.9 & UN South Sudan mission \\
\hline \#juba & 219 & 0.7 & 32 & 0.0 & 27.6 & Capital of South Sudan \\
\hline \#ssudan & 174 & 0.5 & 25 & 0.0 & 24.6 & South Sudan \\
\hline \#bentiu & 142 & 0.4 & 13 & 0.0 & 23.1 & Town in South Sudan \\
\hline \#malakal & 127 & 0.4 & 9 & 0.0 & 22.1 & City in South Sudan \\
\hline civilian & 262 & 0.8 & 173 & 0.1 & 22.0 & Civilians, mainly in South Sudan \\
\hline \#bor & 110 & 0.3 & 18 & 0.0 & 19.3 & Town in South Sudan \\
\hline \#myanmar & 676 & 2.1 & 1,269 & 0.9 & 17.8 & Myanmar \\
\hline \#jonglei & 85 & 0.3 & 20 & 0.0 & 16.2 & State in South Sudan \\
\hline
\end{tabular}

*Z values are for a difference between proportions test for matches and non-matches. 
Table 3. The 10 most retweeted tweets from the corporate UNDP accounts

\begin{tabular}{|c|c|c|}
\hline $\begin{array}{l}\text { Retweets, type, } \\
\text { topic }\end{array}$ & Tweeter & Tweet \\
\hline $\begin{array}{l}894 \text { D } \\
\text { Gender }\end{array}$ & UNDP & $\begin{array}{l}\text { Happy International Women's Day! Picture a world where all women's rights are human rights! \#CSW59 \#IWD2015 } \\
\text { http://t.co/a3cTde8VmD }\end{array}$ \\
\hline $\begin{array}{l}857 \mathrm{E} \\
\text { Gender }\end{array}$ & UNDP & Do good, spread kindness \#EncourageEveryoneln4Words \\
\hline $\begin{array}{l}524 \text { D } \\
\text { Gender }\end{array}$ & UNDP & $\begin{array}{l}\text { Women's rights are \#humanrights. RT if you agree \#IWD2015 \#CSW59 } \\
\text { http://t.co/vqZteSNAG8 }\end{array}$ \\
\hline $\begin{array}{l}359 \mathrm{~N} \\
\text { Gender }\end{array}$ & UNDP & $\begin{array}{l}\text { Pakistani Malala Yousafzai, 17, wins Peace @NobelPrize. Congratulations Malala! \#dayofthegirl } \\
\text { http://t.co/1HFOydoEhs }\end{array}$ \\
\hline $\begin{array}{l}357 \text { P } \\
\text { Gender }\end{array}$ & UNDP & $\begin{array}{l}\text { Female circumcision causes lifelong damage. Girls talk \#EndFGM in our @UNDPEgypt video: } \\
\text { http://t.co/ROT7aVvN7M } \\
\text { http://t.co/zmKb6uMYWO }\end{array}$ \\
\hline $\begin{array}{l}335 \mathrm{E} \\
\text { Corruption }\end{array}$ & UNDP & $\begin{array}{l}\text { Today is Int. Anti-Corruption Day. We all have a part to play in tackling \#corruption, what's yours? \#breakthechain } \\
\text { http://t.co/9moFKfWW } p\end{array}$ \\
\hline $\begin{array}{l}334 \mathrm{E} \\
\text { Corruption }\end{array}$ & UNDP & $\begin{array}{l}\text { Wondering how you can help \#breakthechain \& fight \#corruption? Visit \& find out: } \\
\text { http://t.co/mVSBEsn8D4 @UNODC } \\
\text { http://t.co/LuV5NqbV0N }\end{array}$ \\
\hline $\begin{array}{l}334 \text { D } \\
\text { Gender }\end{array}$ & UNDP & $\begin{array}{l}\text { Women earn 10-30\% less than men for the same work v @UN_Women \#IWD2015 \#Beijing20 } \\
\text { http://t.co/k50mOh4la3 }\end{array}$ \\
\hline $\begin{array}{l}332 \text { D } \\
\text { Gender }\end{array}$ & UNDP & $\begin{array}{l}22 \text { inspiring reasons to celebrate \#IWD2015! Visit our 1st @buzzfeed blog!: } \\
\text { http://t.co/Py99dHDVKP } \\
\text { http://t.co/p7tAczYaq9 }\end{array}$ \\
\hline $\begin{array}{l}294 \text { N } \\
\text { Gender }\end{array}$ & UNDP & $\begin{array}{l}\text { Our Goodwill Ambassador Antonio Banderas stands up to end violence against women. On his birthday, RT \& } \\
\text { support him! } \\
\text { http://t.co/9nEaRH2lon }\end{array}$ \\
\hline
\end{tabular}

Table 4. The 10 most retweeted tweets from the personal UNDP accounts

\begin{tabular}{|c|c|c|}
\hline $\begin{array}{l}\text { Retweets, type, } \\
\text { topic }\end{array}$ & Tweeter type (followers) & Tweet \\
\hline $\begin{array}{l}829 \mathrm{G} \\
\text { Development }\end{array}$ & UNDP director (442) & $\begin{array}{l}\text { With growing economic \& political prominence the South increasingly looks to the South for } \\
\text { solutions to development challenges }\end{array}$ \\
\hline $\begin{array}{l}750 \mathrm{G} \\
\text { Gender }\end{array}$ & Unicef director $(11,200)$ & $\begin{array}{l}\text { Ban Ki-moon on Malala: "The terrorists showed what frightens them most: a girl with a book."v/ @ } \\
\text { UN }\end{array}$ \\
\hline $\begin{array}{l}608 \mathrm{M} \\
\text { Development }\end{array}$ & UNDP director (442) & $\begin{array}{l}\text { Opened today in \#Jakarta, ASEAN Forum Meeting on \#SouthSouth cooperation to explore in- } \\
\text { novative way of development } \\
\text { http://t.co/cEUVUDa5Ru }\end{array}$ \\
\hline $\begin{array}{l}426 \mathrm{P} \\
\text { Press freedom }\end{array}$ & Head of UNDP $(81,500)$ & $\begin{array}{l}\text { Reporters Without Borders just released } 2014 \text { World Press Freedom Index: a link to their map is } \\
\text { attached @RSF_RWB } \\
\text { http://t.co/g6no6KAwiq }\end{array}$ \\
\hline $\begin{array}{l}371 \mathrm{~N} \\
\text { AIDS }\end{array}$ & Head of UNDP $(81,500)$ & $\begin{array}{l}\text { More than } 100 \text { passengers on \#MH17 were going } 2 \text { World \#AIDS Conference in Melbourne: } \\
\text { devastating loss } 2 \text { community. } \\
\text { http://t.co/6toXqOrtYI }\end{array}$ \\
\hline $\begin{array}{l}216 \text { D } \\
\text { Gender }\end{array}$ & Head of UNDP $(81,500)$ & $\begin{array}{l}\text { Today is Intl Day for Elimination of \#ViolenceAgainstWomen. Retweet if u agree that women \& } \\
\text { girls have a right to live free of violence! }\end{array}$ \\
\hline $\begin{array}{l}205 \mathrm{~N} \\
\text { Environment }\end{array}$ & UNDP employee (419) & $\begin{array}{l}\text { Berlin street art: "Politicians discussing global warming." \#climate \#art } \\
\text { http://t.co/IztZqJaxY1 }\end{array}$ \\
\hline $\begin{array}{l}178 \mathrm{~N} \\
\text { Human rights }\end{array}$ & Head of UNDP $(81,500)$ & $\begin{array}{l}\text { Nelson \#Mandela was the visionary leader of our times; an inspiration } 4 \text { his commitment } 2 \\
\text { \#humanrights. RIP \#Madiba. } \\
\text { http://t.co/AsknXI3kWD }\end{array}$ \\
\hline $\begin{array}{l}167 \mathrm{E} \\
\text { Disaster relief }\end{array}$ & Head of UNDP $(81,500)$ & $\begin{array}{l}\text { Nearly half a million in \#Philippines left homeless following \#Haiyan. Donate here to help @WFP } \\
\text { emergency response: } \\
\text { http://t.co/yt5CdiNrc6 }\end{array}$ \\
\hline $\begin{array}{l}162 \mathrm{~A} \\
\text { Inequality }\end{array}$ & UNDP employee $(46,100)$ & $\begin{array}{l}\text { People killed annually by Sharks } 10 \text { Elephants } 100 \text { Snails 10,000 Snakes 50,000 People 475,000 } \\
\text { Mosquitoes } 725,000 \\
\text { http://t.co/RisjaBZcQu }\end{array}$ \\
\hline
\end{tabular}


Table 5. Most retweeted tweets from nine Oxfam accounts

\begin{tabular}{|c|c|c|}
\hline RT & Tweeter & Tweet \\
\hline 2400 & Oxfamgb & $\begin{array}{l}\text { What does it really mean to live under the \#Gaza blockade every day? RT to share our call for an end to this now. } \\
\text { http://t.co/NvhAGkm8ap }\end{array}$ \\
\hline 1395 & Oxfamgb & $\begin{array}{l}\text { 240,000 in Gaza have fled homes and have nowhere to go. This must end - RT to join call for a ceasefire now. } \\
\text { http://t.co/BubpamG0OZ }\end{array}$ \\
\hline 980 & Oxfam & $\begin{array}{l}\text { Staggering \#inequality: top } 1 \% \text { will own } 50 \% \text { of world's wealth by } 2016 . \text { You can help \#EvenitUp! } \\
\text { http://t.co/176qNENAXj } \\
\text { http://t.co/rfMHKmVWRq }\end{array}$ \\
\hline 936 & Oxfam & $\begin{array}{l}\text { Around } 215,000 \text { people have fled their homes but the borders are shut and people have nowhere safe to go. \#Gaza } \\
\text { http://t.co/ZaoSFLLRHA }\end{array}$ \\
\hline 727 & Oxfam & $43 \%$ of \#Gaza's total territory has now been warned to evacuate. But borders are closed. Where are people supposed to go? \\
\hline 551 & Oxfam & $\begin{array}{l}\text { Wow: est 100,000 people, over } 4 \text { miles of NYC streets. } 100 \text { \#PeoplesClimate tweets/minute. photo @cynryan } \\
\text { http://t.co/zo5/94EQhP }\end{array}$ \\
\hline 539 & Oxfam & $\begin{array}{l}\text { Unless things change, by } 2016 \text { wealth of the top } 1 \% \text { will exceed that of the rest of the world } \\
\text { http://t.co/o1EwiTc6xR } \\
\text { http://t.co/B9osgHR4Ee }\end{array}$ \\
\hline 486 & Oxfam & $\begin{array}{l}\text { Ceasefire broken after just 3hrs.RT if, like us, you believe in these } 3 \text { steps to lasting peace in Gaza. \#ceasefirenow } \\
\text { http://t.co/LDPKqrYOuB }\end{array}$ \\
\hline 476 & Oxfamgb & $\begin{array}{l}150 \text { people trapped in boxes in London this morning, joining our call for the \#Gaza blockade to be lifted. } \\
\text { http://t.co/QQCWX1KLEV }\end{array}$ \\
\hline 462 & Oxfamgb & $\begin{array}{l}6 \text { of } 9 \text { busiest hospitals in Gaza closed or damaged. 1000s of casualties to cope with. RT to call for \#ceasefirenow } \\
\text { http://t.co/mrmFQxRqwc }\end{array}$ \\
\hline
\end{tabular}

\subsection{Properties of the UNDP's most retweeted tweets}

Successful corporate tweets are mostly about gender, although two of the top ten are about corruption (Table 3, see also Harrison, 2010). Tweets from personal accounts cover a wider variety of topics. Although gender is represented by two tweets, development and six other topics are also included. The top tweets were informally classified for the type of activity that they represent using the scheme below, as well as for the overall topic (tables 3,4 ). The classification scheme is different from those previously used for advocacy organizations' tweets (e.g., Guo; Saxton, 2014) to focus more closely on the content of UNDP tweets rather than attempting to fit them to a theory.

- Awareness of issue

- Encouraging action

- News

- Promote report, analysis or video

- Meeting/conference information

- Daily announcements

- Arguments

Calls for action need to originate from high level official accounts in order to have the greatest chance of success

In terms of the type of activity represented by the top tweets, from corporate accounts tweets that mention a specific day (4), calls for activity (3) or news (2) are strongly represented. The top personal tweets cover a wider variety of activities, including news (3) and arguments (2) as well as meetings (1), promoting information (1), day announcements (1), calls for activity (1), and awareness (1). Although the number of tweets is too small to be sure, calls for activity might tend to be most successful when sent from official accounts -especially considering that the one highly retweeted personal account call for action was from the head of the UNDP.

The most retweeted tweets have themes that do not appear in the corresponding retweeting terms tables. For example, \#iwd2015 occurs in four of the most retweeted tweets from corporate accounts (Table 3 ) but is not in Table 1 because its Z-score of 3.8 is too low. This suggests that there were also many \#iwd2015 tweets that were not retweeted, even though some became heavily retweeted.

\section{The importance of novelty on Twitter means that it is difficult to use previous successes as a guide to future action}

\subsection{Analysis of comparator organization: Oxfam}

This analysis is reported only briefly to avoid cluttering the paper by duplicating the above tables with different data. For the top ten Oxfam tweets (from nine official English-language accounts: @Oxfamgb; @Oxfamgbpolicy; @Oxfam; @ Oxfamamerica; @OxfamIFls; @HB_Planning; @Oxfamgbpress; @OxfamTrailwalkerAus; @OxfamScotland), a common theme was Gaza: seven out of ten mentioned the blockade of Gaza, people fleeing the area or damage to hospitals (Table 5). Two further top tweets mentioned the high levels of inequality in the world.

The top terms were: via; \#Syria; in; food; \#BehindTheBrands; \#climatechange; \#ebola; of; crisis; \#southsudan. Some of these terms do not relate to topics and some overlap with the UNDP results. An important new topic is \#Syria, which was not alluded to in the UNDP results. The fifth highest 
Oxfam term, \#BehindTheBrands, is part of Oxfam's campaign to pressure top companies into improving the working conditions of their employees. Except for \#Ebola, some of the more successful Twitter interventions from Oxfam that were not taken up by UNDP seem to be of a type that the UNDP could not emulate for political reasons. It would be difficult for the UNDP to attack multinationals or to comment on politically sensitive issues.

\section{Discussion and conclusions}

An important Resonating Topic Method limitation is that the most important and successful tweets are not necessarily the most retweeted and an organization should keep sight of its overall goals when assessing the results. For example, tweets designed to reach a large audience for the first time might get retweeted most, whereas those encouraging a specific action might be retweeted the least, even though they may contribute disproportionately greater to the organization's goals. More generally, an organization probably needs to have tweets that are successful in all its strategy areas and so it would be a mistake to allow the results of the analysis to narrow the Twitter strategy at the expense of the overall strategy. Encouraging action may well be important for an organization's core goals. Another limitation is that there is no evidence that previously successful Twitter strategies are likely to be successful in the future. It might be the case, for example, that the importance of novelty on Twitter means that it is difficult to use previous successes as a guide to future action.

The comparison with Oxfam could identify successful social media strategies of types that were apparently not employed by the UNDP, although the UNDP may not be able to imitate them for political reasons

Overall the results show that corporate tweets about the UNDP itself were likely to be retweeted but personal UNDP tweets were more likely to be retweeted if they were about specific news events (South Sudan in the sample here). Hence the two sets of Twitter accounts seemed to have a different dynamic. The most retweeted tweets covered different topics and these were presumably the most influential. Popular corporate tweets were mainly about gender and often contained news or related to a specific day. Three contained a call for action, which is encouraging from the perspective of using social media to instigate changes. A logical conclusion to draw is that calls for action need to originate from high level official accounts in order to have the greatest chance of success. The most popular personal tweets were more varied in topic and their less managed approach may have allowed them to have impact in areas that are not covered well by the corporate tweets. Several made arguments that may help to persuade others. The comparison with Oxfam could identify successful social media strategies of types that were apparently not employed by the UNDP, although the UNDP may not be able to imitate them for political reasons.
In terms of the method, the above results are plausible and so the method gives a reasonable and fast way to periodically monitor a social media strategy. It will not necessarily work for all organisations and particularly those with weak social media campaigns because it relies upon some of the campaign being successful. This paper does not present concrete evidence that the method will help an organization to improve its social media use, however, and a more extensive long term study combining offline components is needed for this.

\section{Note}

This work is licensed under a Creative Commons Attribution-NoDerivs 3.0 Unported license: http://creativecommons.org/licenses/by-nd/3.0

\section{References}

Almog-Bar, Michal; Schmid, Hillel (2014). "Advocacy activities of nonprofit human service organizations: A critical review". Nonprofit and voluntary sector quarterly, v. 43, n. 1, pp. 11-35.

https://goo.gl/RieKk2

https://doi.org/10.1177/0899764013483212

Anstead, Nick; O’Loughlin, Ben (2015). "Social media analysis and public opinion: The 2010 UK general election". Journal of computer-mediated communication, v. 20, n. 2, pp. 204-220.

https://doi.org/10.1111/jcc4.12102

Auger, Giselle A. (2013). "Fostering democracy through social media: Evaluating diametrically opposed nonprofit advocacy organizations' use of Facebook, Twitter, and YouTube". Public relations review, v. 39, n. 4, pp. 369-376. https://goo.gl/368ubY https://doi.org/10.1016/j.pubrev.2013.07.013

Baumgartner, Frank R.; Jones, Bryan D.; Mortensen, Peter B. (2014). "Punctuated equilibrium theory: Explaining stability and change in public policymaking". In: Sabatier, Paul A.; Weible, Christopher (eds.). Theories of the policy process ( $3^{\text {rd }}$ ed.). Boulder, CO: Westview Press, pp. 59-103. ISBN: 978 0813349268

Berry, Jeffrey M. (1977). Lobbying for the people: The political behavior of public interest groups. Princeton, NJ: Princeton University Press. ISBN: 9780691611778

Bortree, Denise S.; Seltzer, Trent (2009). "Dialogic strategies and outcomes: An analysis of environmental advocacy groups' Facebook profiles". Public relations review, v. 35, n. 3, pp. 317-319. https://goo.gl/Nt9Kmp https://doi.org/10.1016/j.pubrev.2009.05.002

Briones, Rowena L.; Kuch, Beth; Liu, Brooke F.; Jin, Yan (2011). "Keeping up with the digital age: How the American Red Cross uses social media to build relationships". Public relations review, v. 37, n. 1, pp. 37-43. https://doi.org/10.1016/j.pubrev.2010.12.006

Carroll, Craig E.; Huang-Horowitz, Nell C.; McKeever, Brooke W.; Williams, Natalie (2014). "Key messages and message integrity as concepts and metrics in communica- 
tion evaluation". Journal of communication management, v. 18, n. 4, pp. 386-401.

https://goo.gl/ype45G

https://doi.org/10.1108/JCOM-06-2012-0052

Casey, John (2011). Understanding advocacy: A primer on the policy-making role of non-profit organizations. New York: Baruch College, City University of New York, Center for Nonprofit Strategy.

https://goo.gl/oegXGG

Cha, Meeyoung; Haddadi, Hamed; Benevenuto, Fabrício; Gummadi, Krishna P. (2010). "Measuring user influence in Twitter: The million follower fallacy". In: Proceedings of the $4^{\text {th }}$ Int I AAAl conf on weblogs and social media (ICWSM2010). Menlo Park, CA: Alll Press, pp. 10-17.

http://Twitter.mpi-sws.org/icwsm2010_fallacy.pdf

Covey, Jane G. (1995). "Accountability and effectiveness in NGO policy alliances". Journal of international development, v. 7, n. 6, pp. 857-867.

https://goo.gl/i9cCkn

https://doi.org/10.1002/jid.3380070605

Cugelman, Brian; Otero, Eva (2010). Evaluation of Oxfam GB's climate change campaign. Oxford, UK: Oxfam. http://policy-practice.Oxfam.org.uk/publications/evaluationof-Oxfam-gbs-climate-change-campaign-119438

Cugelman, Brian; Thelwall, Mike; Dawes, Phil (2011). "Online interventions for social marketing health behavior change campaigns: A meta-analysis of psychological architectures and adherence factors". Journal of medical internet research, v. 13, n. 1, e17.

https://doi.org/10.2196/jmir.1367

Dury, Sarah; De-Donder, Liesbeth; De-Witte, Nico; Buffel, Tine; Jacquet, Wolfgang; Verté, Dominique (2015). "To volunteer or not: The influence of individual characteristics, resources, and social factors on the likelihood of volunteering by older adults". Nonprofit and voluntary sector quarterly, v. 44, n. 6, pp. 1107-1128

https://goo.gl/AqsuX7

https://doi.org/10.1177/0899764014556773

Edwards, Heather R.; Hoefer, Richard (2010). "Are social work advocacy groups using web 2.0 effectively?". Journal of policy practice, v. 9, n. 3-4, pp. 220-239.

https://goo.gl/byUGms

http://dx.doi.org/10.1080/15588742.2010.489037

Fox, Jonathan (2010). "The uncertain relationship between transparency and accountability". In: Cornwall, Andrea; Eade, Deborrah (eds.). Deconstructing development discourse: Buzzwords and fuzzwords. Rugby, UK: Practical action publishing, pp. 245-256. ISBN: 9781853397066 https://goo.gl/aMQ8QG

Gálvez-Rodríguez, María-del-Mar; Caba-Pérez, Carmen; López-Godoy, Manuel (2014). "Drivers for the proactive online disclosure of information in the NGO sector: the Colombian case". Online information review, v. 38, n. 6, pp. 769-787.

https://doi.org/10.1108/OIR-05-2014-0113
Gerbaudo, Paolo (2012). Tweets and the streets: Social media and contemporary activism. London, UK: Pluto Press. ISBN: 9780745332499

Ghonim, Wael (2012). Revolution 2.0: The power of the people is greater than the people in power: A memoir. New York: Houghton Mifflin Harcourt. ISBN: 9780547773988

Gormley, William T.; Cymrot, Helen (2006). "The strategic choices of child advocacy groups". Nonprofit \& voluntary sector quarterly, v. 35, n. 1, pp. 102-122.

https://goo.gl/PQbj1Z

https://doi.org/10.1177/0899764005282484

Guidry, Jeanine; Waters, Richard; Saxton, Gregory D. (2014). "Moving social marketing beyond personal change to social change: Strategically using Twitter to mobilize supporters into vocal advocates". Journal of social marketing, v. 4, n. 3, pp. $240-260$.

https://goo.gl/gCbf6N

https://doi.org/10.1108/JSOCM-02-2014-0014

Guo, Chao; Saxton, Gregory (2010). "Voice-in, voice-out: Constituent participation and non-profit advocacy". Nonprofit policy forum, v. 1, n. 1, Article 5.

https://doi.org/10.2202/2154-3348.1000

Guo, Chao; Saxton, Gregory (2014). "Tweeting social change: How social media are changing nonprofit advocacy". Nonprofit and voluntary sector quarterly, v. 43, n. 1, pp. 57-79.

https://goo.gl/WA9fKz

https://doi.org/10.1177/0899764012471585

Hall, Nina L.; Taplin, Ros (2007). "Revolution or inch-byinch? Campaign approaches on climate change by environmental groups". The environmentalist, v. 27, n. 1, pp. 95-107. https://goo.gl/tRvTs4

https://doi.org/10.1007/s10669-007-9022-y

Harrison, Elizabeth (2010). "Corruption”. In: Cornwall, Andrea; Eade, Deborrah (eds.) Deconstructing development discourse: Buzzwords and fuzzwords. Rugby, UK: Practical action publishing, pp. 257-264. ISBN: 9781853397066 https://goo.gl/yrnVBB

Howard, Philip N.; Hussain, Muzammil M. (2013). Democracy's fourth wave? Digital media and the Arab Spring. Oxford, UK: Oxford University Press. ISBN: 9780199936977

Karaduman, Ilkay (2013). "The effect of social media on personal branding efforts of top level executives". Procedia-social and behavioral sciences, v. 99, (6 November), pp. 465-473. https://goo.gl/Y9yMgy https://doi.org/10.1016/j.sbspro.2013.10.515

Katz, Elihu (1957). "The two-step flow of communication: An up-to-date report on an hypothesis". Public opinion quarterly, v. 21, n. 1, pp. 61-78. https://doi.org/10.1086/266687

Khan, Gohar F.; Young-Yoon, Ho; Kim, Jiyoung; Woo-Park, Han (2014). "From e-government to social government: Twitter use by Korea's central government". Online information review, v. 38, n. 1, pp. 95-113.

https://goo.gl/Ft7r5i

https://doi.org/10.1108/OIR-09-2012-0162 
Kim, Daejoong; Chun, Heasun; Kwak, Youngsun; Nam, Yoonjae (2014). "The employment of dialogic principles in website, Facebook, and Twitter platforms of environmental nonprofit organizations". Social science computer review, v. 32, n. 5, pp. 590-605.

https://goo.gl/AcFHxJ

https://doi.org/10.1177/0894439314525752

Lovejoy, Kristen; Saxton, Gregory D. (2012). “Information, community, and action: How nonprofit organizations use social media". Journal of computer-mediated communication, v. 17, n. 3, pp. 337-353.

https://doi.org/10.1111/j.1083-6101.2012.01576.x

Lovejoy, Kristen; Waters, Richard D.; Saxton, Gregory D. (2012). "Engaging stakeholders through Twitter: How nonprofit organizations are getting more out of 140 characters or less". Public relations review, v. 38, n. 2, pp. 313-318. https://goo.gl/qSaB34

https://doi.org/10.1016/j.pubrev.2012.01.005

Mason, Dyana P. (2016). "Recognition and cross-cultural communications as motivators for charitable giving: A field experiment". Nonprofit and voluntary sector quarterly, v. 45, n. 1, pp. 192-204.

https://doi.org/10.1177/0899764015576408

McKay, Amy M. (2011). "The decision to lobby bureaucrats". Public choice, v. 147, n. 1-2, pp. 123-138.

https://doi.org/10.1007/s11127-010-9607-8

Mosley, Jennifer E. (2011). “Institutionalization, privatization, and political opportunity: What tactical choices reveal about the policy advocacy of human service nonprofits". Nonprofit \& voluntary sector quarterly, v. 40, n. 3, pp. 435-457.

https://goo.gl/FBD3Lh

https://doi.org/10.1177/0899764009346335

Neiger, Brad; Thackeray, Rosemary; Burton, Scott; Giraud-Carrier, Christophe; Fagen, Michael (2013). "Evaluating social media's capacity to develop engaged audiences in health promotion settings: Use of Twitter metrics as a case study". Health promotion practice, v. 14, n. 2, pp. 157-162. https://goo.gl/qNLFej

https://doi.org/10.1177/1524839912469378

Neiger, Brad L.; Thackeray, Rosemary; Burton, Scott; Thackeray, Callie R.; Reese, Jennifer H. (2013). "Use of Twitter among local health departments: An analysis of information sharing, engagement, and action". Journal of medical internet research, v. 15, n. 8, e177.

https://goo.gl/Jeje3Y

https://doi.org/10.2196/jmir.2775

Obar, Jonathan A.; Zube, Paul; Lampe, Clifford (2012). "Advocacy 2.0: An analysis of how advocacy groups in the United States perceive and use social media as tools for facilitating civic engagement and collective action". Journal of information policy, v. 2, n. 1, pp. 1-25.

https://papers.ssrn.com/sol3/papers.cfm?abstract_ id $=1956352$

https://doi.org/10.5325/jinfopoli.2.2012.0001

Petrovic, Sasa; Osborne, Miles; Lavrenko, Victor (2011). "RT to win! Predicting message propagation in Twitter". In: Proce- edings of the $5^{\text {th }}$ Intl AAAl conf on weblogs and social media (ICWSM2011). Menlo Park, CA: Alll Press, pp. 586-589.

https://www.aaai.org/ocs/index.php/ICWSM/ICWSM11/ paper/viewFile/2754/3209

Phethean, Christopher; Tiropanis, Thanassis; Harris, Lisa (2013). "Rethinking measurements of social media use by charities: a mixed methods approach". In: Proceedings of the $5^{\text {th }}$ Annual ACM web science conf. New York: ACM Press, pp. 296-305.

https://goo.gl/hTBAMj

Ramanadhan, Shoba; Mendez, Samuel R.; Rao, Megan; Viswanath, Kasisomayajula (2013). "Social media use by community-based organizations conducting health promotion: A content analysis". BMC public health, v. 13, n. 1, 1129.

https://doi.org/10.1186/1471-2458-13-1129

Rist, Gilbert (2014). The history of development. From Western origins to global faith. London, UK: Zed Books Ltd. ISBN: 9781783600229

https://goo.gl/StVJjF

Saxton, Gregory D.; Neely, Daniel; Guo, Chao (2014). "Web disclosure and the market for charitable contributions". Journal of accounting and public policy, v. 33, n. 2, pp. 127-144. https://papers.ssrn.com/sol3/papers.cfm?abstract $i d=1912966$

https://doi.org/10.1016/j.jaccpubpol.2013.12.003

Saxton, Gregory D.; Wang, Lili (2014). "The social network effect: The determinants of giving through social media". Nonprofit and voluntary sector quarterly, v. 43, n. 5, pp. 850-868.

https://papers.ssrn.com/sol3/papers.cfm?abstract_ $i d=2247138$

https://doi.org/10.1177/0899764013485159

Saxton, Gregory D.; Waters, Richard (2014). "What do stakeholders like on Facebook? Examining public reactions to nonprofit organizations' informational, promotional, and community-building messages". Journal of public relations research, v. 26, n. 3, pp. 280-299.

https://papers.ssrn.com/sol3/papers.cfm ?abstract_ $i d=2536982$

http://dx.doi.org/10.1080/1062726X.2014.908721

Shaker, Genevieve G.; Borden, Victor M.; Kienker, Brittany L. (2016). "Workplace giving in universities. A US case study at Indiana University". Nonprofit and voluntary sector quarterly, v. 45, n. 1, pp. 87-111. https://doi.org/10.1177/0899764014565468

Soroka, Stuart (2002). Agenda-setting dynamics in Canada. Vancouver, Canada, University of British Columbia Press. https://goo.gl/FVXimM

Suh, Bongwon; Hong, Lichan; Pirolli, Peter; Chi, Ed H. (2010). "Want to be retweeted? Large scale analytics on factors impacting retweet in Twitter network". In: 2010 IEEE $2^{\text {nd }}$ Intl conf on social computing (Socialcom). Los Alamitos: IEEE Press, pp. 177-184.

http://www.parc.com/content/attachments/want-to-beretweeted.pdf 
Sundstrom, Beth; Briones, Rowena L.; Janoske, Melissa (2013). “Expecting the unexpected: Non-profit women's organizations' media responses to anti-abortion terrorism". Journal of communication management, v. 17, n. 4, pp. 341-363. https://doi.org/10.1108/JCOM-08-2012-0069

Svensson, Per G.; Mahoney, Tara Q.; Hambrick, Marion E. (2015). "Twitter as a communication tool for nonprofits: A study of sport-for-development organizations". Nonprofit and voluntary sector quarterly, v. 44, n. 6, pp. 1086-1106. https://doi.org/10.1177/0899764014553639

Thrall, A. Trevor; Stecula, Dominik; Sweet, Diana (2014). "May we have your attention please? Human-rights NGOs and the problem of global communication". The international journal of press/politics, v. 19, n. 2, pp. 135-159.

https://goo.gl/VtR55v

https://doi.org/10.1177/1940161213519132

UN (2015). United Nations millennium development goals. UN. http://www.un.org/millenniumgoals

UNDP (2014). Annual report 2013-14. UNDP.

http://www.UNDP.org/content/UNDP/en/home/librarypage/corporate/annual-report-2014

Vaccari, Cristian; Valeriani, Augusto; Barberá, Pablo; Bon- neau, Rich; Jost, John; Nagler, Jonathan; Tucker, Joshua A. (2015). "Political expression and action on social media: Exploring the relationship between lower- and higher-threshold political activities among Twitter users in Italy". Journal of computer-mediated communication, v. 20, n. 2, pp. 221-239. https://doi.org/10.1111/jcc4.12108

Vergeer, Maurice; Hermans, Liesbeth (2013). “Campaigning on Twitter: Microblogging and online social networking as campaign tools in the 2010 general elections in The Netherlands". Journal of computer-mediated communication, v. 18, n. 4, pp. 399-419.

https://doi.org/10.1111/jcc4.12023

Westerman, David; Spence, Patric R.; Van-Der-Heide, Brandon (2014). "Social media as information source: Recency of updates and credibility of information". Journal of computer-mediated communication, v. 19, n. 2, pp. 171-183. https://doi.org/10.1111/jcc4.12041

Wu, Shaomei; Hofman, Jake M.; Mason, Winter A.; Watts, Duncan J. (2011). "Who says what to whom on Twitter". In: Proceedings of the $20^{\text {th }}$ intl conf on World Wide Web (WWW2011). New York: ACM Press, pp. 705-714 http://www.wwwconference.org/proceedings/www2011/ proceedings/p705.pdf

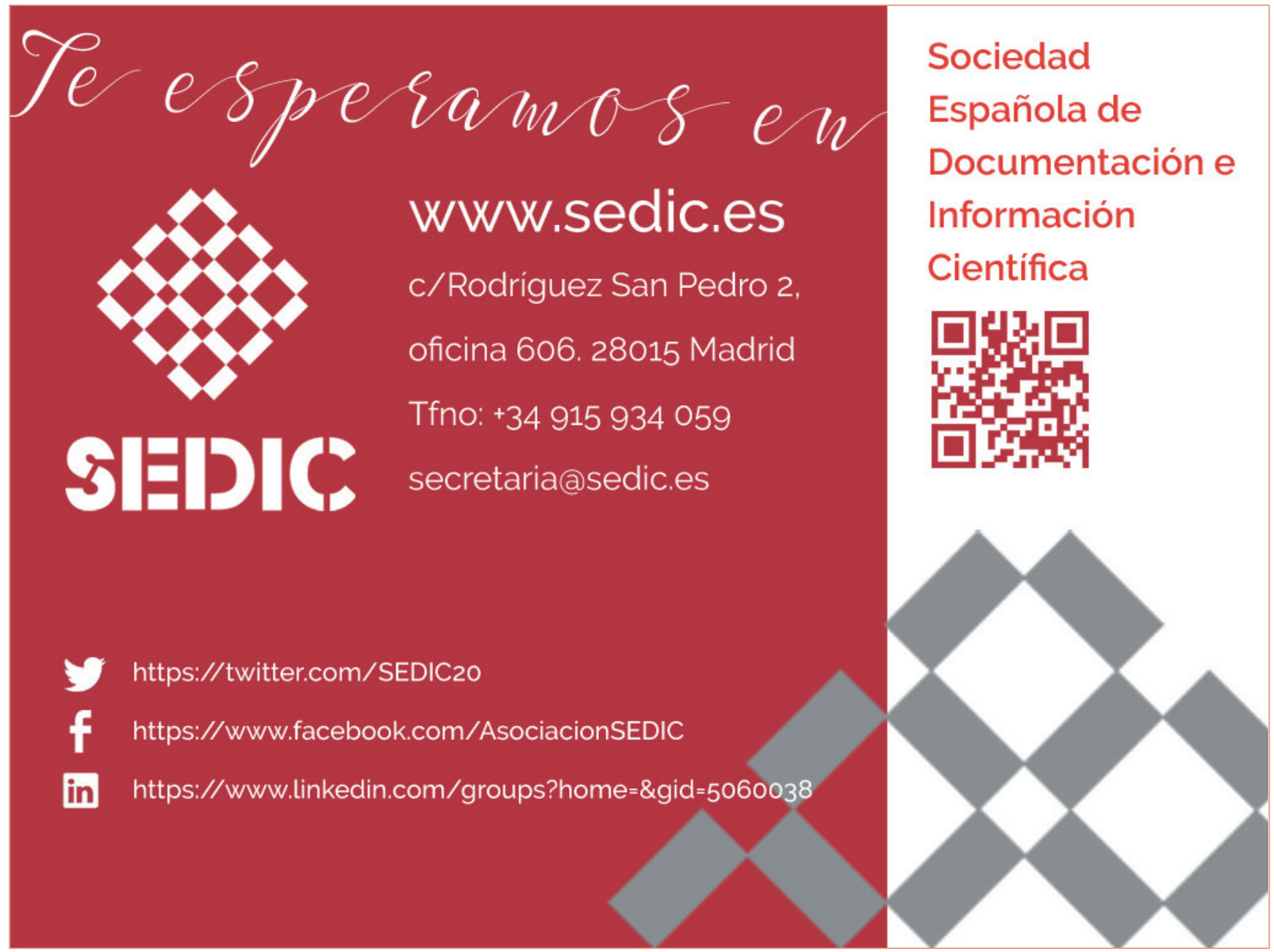

